\title{
SUMBER DAYA UDANG LAUT-DALAM DI INDONESIA DAN KEMUNGKINAN PEMANFAATANNYA SECARA BERKELANJUTAN
}

\author{
Ali Suman ${ }^{1)}$ dan Fayakun Satria ${ }^{2)}$ \\ 1) Peneliti pada Balai Riset Perikanan Laut, Muara Baru-Jakarta \\ 2) Peneliti pada Pusat Penelitian Pengelolaan Perikanan dan \\ Konservasi Sumber Daya Ikan, Ancol-Jakarta \\ Teregistrasi I tanggal: 8 Oktober 2009; Diterima setelah perbaikan tanggal: 19 Oktober 2010; \\ Disetujui terbit tanggal: 29 Oktober 2010
}

\begin{abstract}
ABSTRAK
Sumber daya udang laut-dalam merupakan sumber daya masa depan yang penting bagi pembangunan perikanan di Indonesia. Komposisi jenis sumber daya udang laut dalam ini didapatkan lebih dari 38 jenis dengan jenis yang mendominansi udang Penaeid (Plesiopenaeus edwardsianus). Pola pertumbuhannya adalah allometris dengan penyebaran terpusat pada kedalaman 200-500 m. Potensi penangkapan udang laut-dalam di perairan kawasan barat Indonesia sekitar 640 ton/tahun dengan upaya optimum 285 unit bubu dan di kawasan timur Indonesia sekitar 2.840 ton/tahun dengan upaya optimum 1.250 unit bubu. Rekomendasi pola pemanfaatan udang laut dalam yang berkelanjutan adalah dengan menerapkan opsi pengelolaan berupa penutupan daerah dan musim penangkapan, pembatasan upaya, dan penerapan kuota.
\end{abstract}

KATAKUNCI: sumber daya udang laut-dalam, pemanfaatan secara berkelanjutan, Indonesia

ABSTRACT: The deep-sea shrimp in Indonesia and possibility of its sustainable exploitation. By: Ali Suman and Fayakun Satria

Deep-sea shrimp resources is the future important resources for fisheries development in Indonesia. The catch composition of deep-sea shrimp found more than 38 species and the dominant species is Plesiopenaeus edwardsianus. The growth pattern is allometric with distribution in depth of $200-500 \mathrm{~m}$. Potential yield of deep-sea shrimp in Indonesian western area is 640 ton/year with optimum effort about 285 unit of trap and in Indonesian eastern area is 2,840 ton/year with optimum effort about 1,250 unit of trap. The sustainable exploitation pattern of deep-sea shrimp is recommended to application of management options close area and fishing season, effort limitation, and quota application.

KEYWORDS: deep-sea shrimp resources, sustainable exploitation, Indonesia

\section{PENDAHULUAN}

Sampai saat ini sumber daya udang Indonesia yang telah dimanfaatkan pada umumnya berasal dari wilayah perairan laut dangkal yaitu pada kedalaman kurang dari $200 \mathrm{~m}$. Wilayah penangkapan udang tersebut menyebar meliputi 11 wilayah pengelolaan perikanan mulai dari wilayah pengelolaan perikanan Selat Malaka di ujung barat sampai wilayah pengelolaan perikanan Laut Arafura di sebelah timur. Secara umum, seluruh wilayah pengelolaan perikanan tersebut dikatakan telah 
mengalami tekanan penangkapan yang tinggi dan bahkan cenderung sudah mengalami lebih tangkap. Apabila kondisi ini dibiarkan dalam jangka panjang tanpa adanya usaha pengelolaan dan pemanfaatan yang berkelanjutan, maka akan menyebabkan kelestarian sumber daya udang akan terancam dan bahkan dapat punah. Salah satu hal yang dilakukan dalam mengantisipasinya adalah mencari daerah penangkapan baru, dan perairan lautdalam merupakan wilayah perairan dengan sumber daya udang yang potensial dan belum pernah dimanfaatkan (untapped resources).

Indonesia merupakan negara yang memiliki wilayah laut-dalam yang luas dan memiliki potensi sumber daya udang lautdalam yang secara komersial dapat dimanfaatkan. Pemerintah Indonesia juga sangat berkeinginan untuk dapat mengembangkan sektor perikanan tangkapnya terutama di wilayah yang belum dimanfaatkan sebagai upaya untuk mendukung program pemerintah yang ingin membuka lapangan kerja baru (projob), mengentaskan kemiskinan (propoor), dan mendorong pertumbuhan ekonomi di sektor perikanan tangkap (progrowth), termasuk menciptakan iklim usaha bidang perikanan tangkap yang kondusif. Selain itu pengembangan pemanfaatan sumber daya udang laut-dalam ini sekaligus juga mendukung pencapaian visi Departemen Kelautan dan Perikan sebagai penghasil produk kelautan dan perikanan terbesar pada tahun 2015.

Penelitian mengenai sumber daya udang laut-dalam di Indonesia dimulai oleh George (1967) dengan menemukan udang penaeid laut dalam di Laut Flores, Selat Makassar, Laut Banda, dan Laut Arafura, kemudian diikuti dengan penemuan udang Solenocera promintes pada kedalaman $200 \mathrm{~m}$ di sebelah selatan Jawa oleh kapal Korea $\mathrm{OH}$
DAE SAN. Penelitian untuk mengetahui stok udang laut-dalam di perairan Kai, Aru, dan Tanimbar dilakukan dalam kerangka Ekspedisi KARUBAR, untuk laut-dalam di sebelah selatan Jawa dilakukan dengan kapal Umitaka Maru. Kegiatan tersebut diikuti dengan penelitian stok sumber daya udang laut-dalam di perairan Samudera Hindia sebelah selatan Jawa dan barat Sumatera dalam kerangka The JapanIndonesia Deep Sea Fishery Resources Joint Exploration Project pada tahun 2004 dan 2005.

\section{SUMBER DAYA UDANG LAUT-DALAM DI INDONESIA}

\section{Komposisi Jenis dan Penyebaran}

Informasi tentang komposisi hasil tangkapan dalam jangka panjang merupakan salah satu informasi dasar bagi kajian dinamika komunitas sumber daya ikan, teknologi alat tangkap yang digunakan, dan interaksi antar spesies atau kelompok spesies. Komposisi jenis udang laut dalam di perairan kawasan timur Indonesia dikelompokan menjadi dua kelompok besar yaitu udang (prawn) dan lobster (scampi). Jenis udang yang diperoleh terdiri atas 24 jenis yang dapat digolongkan menjadi lima famili, yaitu Aristaeidae, Pandalidae, Penaeidae, Nematocarcinidae, dan Sicyonidae. Lobster terdiri atas 12 jenis yang dapat dikelompokan menjadi lima famili, yaitu Scyllaridae, Palinuridae, Nephropidae, Polychelidae, dan Thalassinida. Beberapa jenis udang lautdalam yang dapat dikategorikan mempunyai nilai ekonomis penting antara lain jenis Aristeus virilis, Aristeomorpha foliace, Heterocarpus woodmasoni, dan Haliporoides sibogae, dan untuk jenis lobster yang cukup penting meliputi Metanephrops sibogae dan Nephropsis ensirostris. 
Komposisi jenis udang laut-dalam di kawasan barat Indonesia pada daerah Samudera Hindia sebelah selatan Jawa didapatkan 38 jenis dengan jenis yang dominan udang penaeid (Plesiopenaeus edwardsianus) dan hal ini mengindikasikan habitat dasar perairan selatan Jawa terdiri atas lumpur, yang merupakan habitat utama udang penaeid. Selain itu di perairan selatan Jawa didapatkan juga jenis lobster ekonomis penting, Metanephrops andamanicus, yang mendominansi hasil tangkapan. Di perairan Australia lobster ini menjadi komoditas ekonomis penting dalam perikanan udang laut-dalam dan dengan ditemukannya jenis ini nantinya akan dapat dijadikan salah satu hasil tangkapan yang potensil untuk dikembangkan di perairan ini. Jenis yang agak berbeda ditemukan pada daerah Samudera Hindia sebelah barat Sumatera, di mana dari 33 jenis yang ditemukan di perairan ini terlihat didominansi oleh udang Pandalidae yaitu jenis Heterocarpus sp. Hal ini mengindikasikan bahwa dasar perairan di wilayah perairan tersebut merupakan karang-karang, yang sangat berbeda dengan dasar perairan laut-dalam di kawasan timur Indonesia dan beberapa daerah di kawasan barat Indonesia. Secara umum, jenis udang laut-dalam yang ditemukan di perairan Indonesia adalah didominansi oleh jenis ekonomis penting seperti yang sudah dimanfaatkan di perairan Australia dan Kepulauan Pasifik. Dengan demikian sumber daya udang laut-dalam yang ada di perairan Indonesia sangat berprospek untuk diusahakan secepat mungkin.

Sementara itu pola pertumbuhan jenis udang laut-dalam yang diamati menunjukan pertumbuhan yang mengikuti pola allometris yang berarti pertambahan panjangnya tidak secepat pertambahan bobotnya, sama seperti yang ditemukan pada udang laut dalam di perairan Australia.
Untuk komposisi ukuran setiap jenis udang menunjukan udang betina selalu ditemukan lebih panjang dari udang jantan serta betina selalu lebih banyak dari udang jantan. Fenomena ini menunjukan bahwa populasi sumber daya udang laut-dalam masih dalam kondisi yang baik karena dengan ditemukannya udang betina lebih banyak menunjukan pembaruan populasi (recovery) akan terjamin dengan baik. Selain itu komposisi ukuran jenis udang yang menunjukan kisaran yang luas menunjukan bahwa udang laut-dalam tersebut dalam satu populasi terdiri atas beberapa kohort.

Selanjutnya pola penyebaran menunjukan bahwa udang laut-dalam di perairan kawasan timur Indonesia dan kawasan barat Indonesia terkonsentrasi pada kedalaman 200-500 m. Jenis udang yang memiliki penyebaran yang sangat luas adalah udang penaeid (Plesiopenaeus edwardsianus, Aristeus virilis) dan fenomena lain penyebarannya menunjukan bahwa makin bertambah kedalaman akan diikuti oleh makin besarnya ukuran udangudang yang tertangkap.

\section{Alat Penangkapan}

Sampai saat ini pemanfaatan sumber daya udang laut-dalam belum dilakukan di Indonesia, jadi belum ada alat tangkap yang beroperasi untuk pemanfaatannya. Tetapi melihat potensi yang ada, maka alat tangkap yang layak untuk dikembangkan mengusahakannya adalah bubu. Bubu tersebut telah diuji-coba dalam percobaan penangkapan udang laut-dalam di perairan Indonesia. Rancangannya didasarkan atas pengetahuan dan pengalaman penelitipeneliti alat dan teknologi penangkapan ikan Balai Penelitian Perikanan Laut. Di samping itu bahan-bahan juga diperoleh dari pustaka tentang hasil-hasil penelitian dari negara lain yang sudah mengadakan penelitian atau usaha penangkapan komersil 
mengenai udang dan ikan laut dalam. Beberapa negara yang telah melakukan penelitian tentang udang laut dalam antara lain Australia, Papua New Guinea, dan negara-negara lain di kawasan lautan Pasifik.

Tiga bubu laut-dalam yang digunakan adalah bubu lipat, silinder, dan trapezium dan didapatkan hasil tangkapan udang tertinggi pada bubu lipat dan silinder, oleh karena itu maka kedua tipe bubu ini yang layak untuk dikembangkan. Bubu lipat dan silinder ternyata praktis dan mudah merakitnya di atas kapal saat sebelum dioperasikan karena dapat dikerutkan atau dilipat, dengan demikian akan memudahkan dalam penyimpanan dan pengangkutannya. Kedua tipe bubu ini dapat dioperasikan dalam jumlah banyak meskipun menggunakan kapal berukuran kecil, karena jenis alat tangkap ini tidak memerlukan tempat yang luas dalam pengangkutannya.

\section{Potensi Penangkapan}

Bagi keperluan perencanaan pengembangan potensi baru sumber daya udang laut-dalam di suatu daerah diperlukan pengetahuan tentang besarnya potensi penangkapan. Hasil penelitian di perairan laut dalam kawasan barat Indonesia menunjukan bahwa kepadatan stok udang laut dalam pada daerah Zona Ekonomi Ekslusif Samudera Hindia selatan Jawa berkisar antara 8-399 kg/km². Stasiun yang paling rendah kepadatan stoknya di sebelah selatan Cilacap dan yang tertinggi pada stasiun di sebelah selatan Yogyakarta. Secara spasial, terlihat kepadatan stok lebih tinggi di perairan bagian barat yaitu di sekitar perairan selatan Jawa Tengah, bila dibandingkan di bagian timur yang meliputi wilayah perairan selatan Jawa Timur. Untuk Zona Ekonomi Ekslusif Samudera Hindia sebelah barat Sumatera ditemukan kepadatan stoknya berkisar antara 2,0-91 $\mathrm{kg} / \mathrm{km}^{2}$, kepadatan stok tertinggi terdapat pada daerah sebelah barat Pulau Enggano dan terendah terdapat di daerah sebelah barat Aceh. Apabila dilihat per daerah didapatkan kepadatan stok udang lautdalam lebih tinggi di perairan selatan Jawa dibandingkan dengan perairan sebelah barat Sumatera. Secara umum, potensi penangkapan udang laut-dalam di perairan kawasan barat Indonesia sekitar 568 ton per tahun untuk daerah Zona Ekonomi Ekslusif Samudera Hindia sebelah selatan Jawa dan 72 ton per tahun untuk daerah Zona Ekonomi Ekslusif Samudera Hindia sebelah barat Sumatera.

Fenomena di perairan kawasan timur Indonesia menunjukan bahwa potensi penangkapannya jauh lebih tinggi bila dibandingkan dengan daerah kawasan barat Indonesia. Dari indikator kepadatan stok di perairan kawasan timur Indonesia menunjukan kisaran 0,28-1,97 ton $/ \mathrm{km}^{2}$, hal ini mengindikasikan bahwa potensi penangkapan di wilayah ini lima kali lebih tinggi apabila dibandingkan di perairan kawasan barat Indonesia. Potensi penangkapan tertinggi di wilayah ini didapatkan pada di sekitar pulau-pulau kecil seperti Kai, Aru, dan Tanimbar.

\section{PEMANFATAAN SUMBER DAYA UDANG LAUT-DALAM SECARA BERKELANJUTAN}

Sumber daya udang laut-dalam dipandang sebagai sumber daya yang dapat pulih kembali (renewable resources), maka pemanfaatan yang berkelanjutan diartikan sebagai upaya pemanfaatan sumber daya yang laju ekstrasinya tidak boleh melampaui laju kemampuan daya pulihnya. Oleh karena itu rezim pemanfaatan secara terbuka, sebagaimana pada umumnya dianut di Indonesia saat ini, sudah tidak digunakan untuk 
mengusahakan sumber daya ini. Sampai saat ini pemanfaatan sumber daya udang laut dalam belum dilakukan di Indonesia, dengan demikian telah terjadi pemborosan, karena membuang percuma sumber daya yang ada tanpa dapat digunakan sebesarbesarnya bagi kemakmuran rakyat. Setiap tahun surplus produksi dari stok yang ada akan mengalami kematian alamiah tanpa sempat digunakan untuk meningkatkan produksi perikanan.

Dari berbagai macam cara pengelolaan untuk menuju pemanfaatan sumber daya udang laut-dalam secara berkelanjutan seperti yang telah dikatakan, terlihat tidak seluruhnya dapat diaplikasikan dalam pemanfaatan sumber daya udang laut-dalam di perairan kawasan barat Indonesia dan kawasan timur Indonesia. Pembatasan atau penentuan ukuran udang terkecil yang boleh didaratkan dan ukuran mata jaring yang terkecil tidak dapat dilaksanakan, karena yuwana dari udang yang dilindungi dan udang dewasa dari jenis-jenis udang kecil lainnya terdapat pada daerah yang sama (bercampur). Kesukaran lain adalah jika sebagian hasil tangkap nelayan terdiri atas udang-udang dengan ukuran di bawah ukuran udang terkecil yang telah ditetapkan, akan membuat nelayan membuang kembali hasil tangkapannya ke laut dan akan terbuang percuma karena akan mati sendiri.

Pengaturan ukuran mata jaring juga tidak dapat diterapkan karena metode ini kurang efektif untuk udang laut-dalam karena proses seleksi tidak begitu efisien. Hal ini mengingat udang memiliki rostrum dan appendages (pencuatan-pencuatan) yang akan menghambat lolosnya udang dari mata jaring. Selain itu alat tangkap yang disarankan untuk pemanfaatan sumber daya udang laut-dalam adalah bubu, dengan demikian tidak berkaitan dengan pengaturan ukuran mata jaring.
Dengan demikian dari beberapa metode pengelolaan dan pemanfaatan yang dikatakan untuk menuju pemanfaatan sumber daya udang laut-dalam secara berkelanjutan di perairan Indonesia, ternyata metode yang layak dilaksanakan adalah penutupan musim dan daerah penangkapan, pembatasan upaya penangkapan, dan kuota penangkapan.

Penutupan daerah dan musim penangkapan bertujuan untuk melindungi udang muda dan yuwana serta meningkatkan ukuran udang pertama kali matang kelamin dan akhirnya meningkatkan produksi. Dengan metode ini maka waktu yang krusial yang dibutuhkan oleh udang dalam siklus hidupnya, yaitu mulai memijah, menjadi larva, dan menuju daerah asuhan dalam bentuk post larva, dapat terlindungi, dan dengan demikian akan terjamin kelestarian sumber daya laut dalam.

Penerapan metode pengelolaan dan pemanfaatan berupa pembatasan upaya penangkapan udang laut dalam didasarkan atas hasil penelitian metode sapuan (swept area method). Untuk perairan kawasan barat Indonesia potensi lestari udang lautdalam yang dapat dimanfaatkan 568 ton di Samudera Hindia sebelah selatan Jawa dan 73 ton untuk perairan Samudera Hindia sebelah barat Sumatera. Untuk upaya pemanfaatan sumber daya tersebut sebaiknya difokuskan pada nelayan skala kecil dengan jumlah upaya optimum di perairan selatan Jawa sekitar 250 upaya dan untuk barat Sumatera sekitar 35 upaya. Analog dengan perairan kawasan barat Indonesia, di perairan kawasan timur Indonesia juga dapat dilakukan pemanfaatan sumber daya udang laut-dalam dengan jumlah upaya 1.250 unit upaya bubu dan potensi penangkapan sekitar 2.840 ton per tahun. Dengan demikian setiap tahunnya pemanfaatan sumber daya udang 
laut-dalam ini dapat menyerap tenaga kerja 3.100 orang nelayan, yang berarti pengusahaan sumber daya udang lautdalam ini dapat menjadi sumber kehidupan bagi 15.000 orang rakyat Indonesia terutama penduduk di wilayah pulau-pulau kecil. Untuk alat tangkap yang akan digunakan dalam pemanfaatan sumber daya udang laut-dalam di Indonesia disarankan menggunakan alat tangkap bubu, seperti yang dioperasikan nelayannelayan kecil penangkap udang laut-dalam di negara-negara Kepulauan Pasifik.

Selanjutnya pengelolaan pemanfaatan sumber daya udang laut dalam yang dapat diaplikasikan adalah kuota penangkapan. Kuota penangkapan yang dilakukan adalah dengan membagi potensi penangkapan yang ada berdasarkan atas kemampuan wilayah dalam menangkap udang lautdalam ini. Prinsip kuota ini sangat sejalan juga dengan prinsip otonomi daerah yang mulai berlaku sejak tahun 1999. Berdasarkan atas kemampuan penangkapan udang per wilayah tersebut maka alokasi penangkapan dan alokasi produksi masing-masing wilayah di sekitar daerah penangkapan udang laut-dalam ini.

Dari pola pemanfaatan sumber daya udang laut-dalam yang akan diterapkan di perairan Indonesia, terlihat menjamin pemanfaatan udang laut-dalam secara berkelanjutan yang sesuai dengan kriteria Monintja (2000) sebagai berikut:

1. Hasil tangkapan tidak melebihi jumlah yang boleh dimanfaatkan yaitu pemanfaatan di kawasan timur Indonesia tidak boleh melebihi 2.840 ton per tahun dan di perairan kawasan barat Indonesia tidak boleh melebihi 640 ton per tahun.

2. Menggunakan bahan bakar lebih sedikit, di mana hal ini tercermin dari penggunaan alat tangkap yang disarankan berupa bubu.
3. Secara hukum, alat tangkap legal, di mana seluruh unit armada yang diproyeksikan adalah sesuai dengan peraturan perundang-undangan.

4. Investasi yang dibutuhkan rendah, yang tergambar dari biaya investasi alat tangkap bubu lebih kecil bila dibandingkan dengan alat tangkap trawl.

5. Produk mempunyai pasar yang baik, terutama untuk tujuan ekspor. Dengan strategi ini maka proses produksi telah memperhatikan kaidah-kaidah keberlajutan dan berwawasan lingkungan, dan dengan demikian akan menjamin pasar produk ini di luar negeri.

\section{KESIMPULAN}

1. Dalam rangka pemanfaatan sumber daya udang laut-dalam secara berkelanjutan maka dimulai dari awal pemanfaatannya, dengan mulai mengidentifikasi skenario pengelolaan dan pemanfaatan yang sesuai dengan prinsip-prinsip keberlanjutan.

2. Dalam kaitan pemanfaatan sumber daya udang laut-dalam yang berkelanjutan tersebut maka pilihan yang dapat dilakukan pada awal pengusahaannya adalah melakukan pengendalian jumlah upaya penangkapan sekitar 285 armada bubu di kawasan barat Indonesia dengan produksi yang lestari 640 ton per tahun.

3. Untuk perairan kawasan timur Indonesia jumlah upaya yang direkomendasikan sekitar 1.250 armada bubu laut-dalam dengan produksi yang lestari sekitar 2.840 ton.

4. Skenario pemanfaatan tersebut akan dapat menjadi sumber penghidupan bagi 15.000 orang. 
5. Pilihan pengelolaan penutupan daerah penangkapan dan musim serta kuota dilakukan setelah pengusahaan sumber daya udang laut-dalam dilakukan serta dilakukan penelitian lebih lanjut untuk mendasarinya.

\section{DAFTAR PUSTAKA}

George, M. J. 1967. On a collection of penaeid prawns from the offshore water of the south west India. Proceeding of Symposium on Crustacea. Part 1. 337344.

Monintja, D. R. 2000. Prosiding Pelatihan untuk Pengelolaan Wilayah Pesisir Terpadu. Pusat Kajian Sumber Daya Pesisir dan Lautan. Institut Pertanian Bogor. Bogor. 45-57. 